\title{
RELATO DE EXPERIÊNCIA DO ESTÁGIO SUPERVISIONADO NOS ANOS INICIAIS
}

\author{
Ana Beatriz Oliveira de Medeiros ${ }^{1}$ \\ Yloma Fernanda de Oliveira Rocha ${ }^{2}$
}

RESUMO: O presente artigo tem por objetivo a discussão a respeito do relato de experiência do estágio curricular obrigatório supervisionado realizado de maneira remota em uma turma de $2^{-}$ano do Ensino Fundamental na instituição CETI Governador Freitas Neto. Descrevem-se as atividades realizadas durante um mês de realização do estágio e as contribuições para o desenvolvimento acadêmico.

Palavras- Chave: Estágio. Anos iniciais. Ensino fundamental. Relato de experiência.

ABSTRACT: This article has the purpose of discussing the experience of a curricular mandatory internship remotely supervised that took place in a class of 2nd grade in CETI Governador Freitas Neto. It is described the activities made during the month of the internship and the contributions for the academical development.

Keywords: Internship. Elementary school. Discussing the experience.

\section{INTRODUÇÃO}

O estágio é um momento de suma importância para o desenvolvimento do discente, neste período o mesmo tem a oportunidade de observar e analisar aquilo que foi estudado em sala (teoria) e como está sendo aplicado (prática). "A experiência do estágio é essencial para a formação integral do aluno, considerando que cada vez mais são requisitados profissionais com habilidades e bem preparados. Ao chegar à universidade o aluno se depara com o conhecimento teórico, porém muitas vezes, é difícil relacionar teoria e prática se o estudante não vivenciar momentos reais em que será preciso analisar o cotidiano". (MAFUANI, 20II)

No percorrer da realização do estágio podemos notar a importância de se ter uma gestão competente que dê o apoio necessário para que o docente possa desenvolver suas aulas de forma que o aluno entenda e participe de maneira efetiva.

\footnotetext{
${ }^{\text {I }}$ Aluna do curso de pedagogia. Faculdade de Ensino Superior do Piauí - FAESPI

${ }^{2}$ Pedagoga, Psicóloga, Psicopedagoga, Mestre em Saúde Mental e Transtorno Aditivo, Professora do curso de Pedagogia na Faculdade de Ensino Superior do Piauí da disciplina Estágio Curricular Supervisionado dos Anos Iniciais do Ensino Fundamental.
} 
Infelizmente por conta da disseminação do COVID- I9 (O nome COVID é a junção de letras que se referem a (co)rona (vi)rus (d)isease, o que na tradução para o português seria "doença do coronavírus") muitos alunos se afastaram das aulas por não conseguir ter os materiais necessários para o acesso remoto como o celular, a internet, computador e etc. $\mathrm{Na}$ volta às aulas presenciais percebeu- se que os alunos estavam muito apáticos, distantes, isso fez com que o ensino-aprendizagem ficasse difícil. Os professores tiveram que aprender em um estalar de dedos como utilizar o celular como ferramenta de trabalho, e por muitas vezes sem ajuda do gestor escolar para ensinar, o que pode desmotivar os mesmos para a realização das atividades de ensino.

Outro agravante é a parceria da família com escola, sempre foi importante ter essas duas instituições unidas, porém neste momento em que todos estão vivendo aumentou a necessidade de termos a participação dos responsáveis nas realizações das atividades, inclusive na turma do $2^{-}$ano do ensino fundamental, onde está passando por um período de transição das letras de forma para a cursiva, onde a leitura precisa ser perfeita e que a criança já entenda adição, centena dezena e unidade. Sem o auxilio dos pais/responsáveis nesse momento não teria a possibilidade de obter um bom resultado da aprendizagem do aluno.

\section{METODOLOGIA}

Durante o semestre obteve-se o ensinamento da importância do estágio no desenvolver do acadêmico, para quando o mesmo se tornar pedagogo ter uma experiência prática de como está a educação em seu real contexto. Com a apresentação da escola podese conhecer o ambiente para observação, sabendo sua estrutura, onde está instalado, seu público alvo. Ao conhecer a turma e iniciar a observação notam-se os pontos positivos e negativos no ensino ou na maneira em que o aluno está recebendo isso.

O estágio acompanhando uma instituição pública com uma turma que está de forma remota é de suma importância para analisarmos a forma em que as instituições e a comunidade escolar estão lidando com a mudança repentina devido ao COVID - I9.

\section{RESULTADOS E DISCUSSÃO}

O campo de estágio foi o CETI - Governador Freitas Neto, que está localizada Rua Capitão Vanderley, Sn - Samapi, Teresina - PI, 64059-30o. Escola que trabalha com turmas em tempo integral, amplo espaço aberto, salas climatizadas. 
Precisando de algumas reformas na instituição em relação ao manter do espaço, banheiros com reservatórios quebrados, quadra poliesportiva "abandonada” precisando de limpeza e ajustes, gramas precisando ser aparadas.

O presente estágio foi realizado na turma de $2^{0}$ ano do Ensino Fundamental turno manhã. No período de 14 de setembro a I4 de outubro, cumprindo um mês de realização prática na instituição de forma remota.

\section{I ASPECTOS OBSERVADOS}

As aulas que foram observadas, eram por meio de "WhatsApp", onde foi criado um grupo com os números dos responsáveis, então a professora iniciava a aula enviando mensagem com o tema da aula, depois enviava um áudio explicando a atividade que deveria ser realizada e por último a foto da atividade que era para ser feita. Infelizmente apenas 4 ou 5 alunos respondiam e participavam das aulas, não tinha um envolvimento efetivos com responsáveis para a realização das atividades.

Notou-se desmotivação por parte da professora para realizar as atividades dos alunos, pois não havia um retorno significativo dos pais/responsáveis, e não tinha um apoio por parte da coordenação pedagógica. A relação família X escola, era feita através da professora que ligava para os responsáveis e na maioria das vezes não era atendida, ou recebia mensagens além do seu horário de trabalho.

\subsection{ASPECTOS DOCENTES}

Para auxiliar a professora, fiz vídeos com calendários, figurinhas para enviar no grupo com "bom dia". E me coloquei a disposição para ajuda-la em quaisquer dúvidas em relação às redes sociais, pois a mesma não recebeu um "curso" explicando como utilizar o aplicativo para as aulas.

\section{CONSIDERAÇÃO FINAL}

Durante o estágio na turma de $2^{\circ}$ ano do Ensino Fundamental, pude vivenciar as atividades como futura professora e pedagoga. Sendo de grande aprendizado para a conclusão dessa disciplina de Estágio Curricular Supervisionado Obrigatório.

Pude observar a importância de uma equipe que trabalha em equipe, que o foco principal da escola é o ensinar de maneira que o aluno compreenda a responsabilidade de um professor na vida de uma criança principalmente nos anos iniciais do Ensino Fundamental, em que cada etapa é um processo de transição. 
Também tive a oportunidade de refletir de maneira crítica a cerca da educação de forma remota, como estão passando por esse período que cada vez mais mostra que veio para ficar.

\section{REFERÊNCIAS}

MAFUANI, F. Estágio e sua importância para a formação do universitário. Instituto de

Ensino superior de Bauru. 2011. Disponível em:

http://www.iesbpreve.com.br/base.asp?pag=noticiaintegra.asp\&IDNoticia=I259 